\title{
Availability, pricing and affordability of selected medicines for noncommunicable diseases
}

\author{
Elham Heidari, ${ }^{1}$ Mehdi Varmaghani ${ }^{2}$ and Akbar Abdollahiasl ${ }^{3}$
}

${ }^{1}$ Noncommunicable Diseases Research Center, Endocrinology and Metabolism Population Science Institute, Tehran University of Medical Sciences, Tehran, Islamic Republic of Iran. ${ }^{2}$ Social Determinants of Health Research Center, Mashhad University of Medical Sciences, Mashhad, Islamic Republic of Iran. ${ }^{3}$ Department of Pharmacoeconomics and Pharmaceutical administration, Pharmaceutical Policy Research Center and Faculty of Pharmacy, Tehran University of Medical Sciences, Tehran, Islamic Republic of Iran. (Correspondence to: Akbar Abdollahiasl: abdollahiasl@sina.tums.ac.ir).

\begin{abstract}
Background: The global and national burden of noncommunicable diseases continues to rise, thus making access to medicines increasingly important.

Aims: The objective of this study was to evaluate the availability, pricing, and affordability of selected medicines for noncommunicable diseases in the Islamic Republic of Iran used in 2014 based on the World Health Organization (WHO)/ Health Action International (HAI) methodology.

Methods: The price and availability data for 54 selected medicines were collected from public and private retail pharmacies as well as private pharmacies located in public hospitals in six cities of the Islamic Republic of Iran on the basis of the standardized methodology developed by WHO and HAI. The outcome measures were percentage availability of medicines, ratios of medicine prices to the international reference prices, and the affordability. Affordability was defined as the number of days' wages needed by the lowest-paid unskilled government worker to afford one month of chronic treatment.

Results: The procurement price of the surveyed Lowest Priced Generic and Most Sold Generic medicines was 1.19 times the international reference price. The patient price was not significantly different among different pharmacy retail settings compared with the international reference prices. Moreover, the overall mean availability of the surveyed Lowest Priced Generic medicines in public, private, and other settings was $75.5 \%, 83.3 \%$ and $80.3 \%$, respectively. All the treatment costs for the high burden noncommunicable diseases were less than one day's wages of the lowest-paid government worker.

Conclusions: This study indicated that procurement prices of the surveyed medicines were reasonable in comparison with the international reference price. Moreover, the availability of generic forms of the surveyed medicines was good but originator brand medicines were significantly low in all the three settings.

Keywords: Iran, availability, affordability, health services accessibility, noncommunicable diseases

Citation: Heidari E; Varmaghani M; Abdollahiasl A. Availability, pricing and affordability of selected medicines for noncommunicable diseases. East Mediterr Health J. 2019;25(7):473-480. https://doi.org/10.26719/emhj.18.068

Received: 07/03/17; accepted: 20/11/17

Copyright @ W World Health Organization (WHO) 2019. Some rights reserved. This work is available under the CC BY-NC-SA 3.0 IGO license (https:// creativecommons.org/licenses/by-nc-sa/3.0/igo).
\end{abstract}

\section{Introduction}

The burden of noncommunicable diseases (NCDs) is increasing in the low- and middle- income countries. Such diseases are the dominant causes of death, and it is estimated that cancer, cardiovascular, diabetes, and chronic respiratory diseases are the cause of more than $60 \%$ of all deaths in 2005 (1), and represent $43 \%$ of the burden of diseases and are responsible for the majority of deaths worldwide (2). About $80 \%$ of chronic-disease deaths occur in low- and middle-income countries (3). In the Islamic Republic of Iran, the prevalence of NCDs is high (4) and in the past few decades the main cause of mortality in the country has changed from communicable diseases to NCDs (5).

Due to the high prevalence and burden of diseases, Iranian society needs a reliable supply of lifelong and affordable treatments for patients. Since NCDs require life-long treatment, lack of reliable access to and high price of needed medicines are considered as obstacles to adequate treatment. A fundamental step in improving access to medicines for NCDs in the country is measuring the availability and affordability of essential medicines present in different pharmacy settings. To this end, some background knowledge about the Iranian pharmaceutical market is required. In the Islamic Republic of Iran, the government controls pharmaceutical production/importation in order to make it more affordable and in order to keep the costs contained. In addition, nearly all Iranians use some form of insurance system to compensate for their drug expenses (6). The main stakeholder of pharmaceutical affairs is the Iran Food and Drug Administration (IFDA) that seeks to regulate all aspects of pharmaceutical market under the supervision of the Ministry of Health and Medical Education (MoHME) (7). All pharmacies 
at all settings provide their medicines from the same officially registered distributors except for vaccines and a few medicines for rare diseases.

The price is set at the level of the lowest priced equivalent on the market (patients must pay extra if requesting a higher priced equivalent product). The patient pays a co-payment and the pharmacy claims back the balance from the insurer (6). The premium for insurance coverage is distributed among the employer, the employee, and the government. Both public and private settings are dealt with the same way by the insurance system, which is responsible for reimbursement of medicines. Thus, the whole health system's mission is to provide sufficient, accessible and affordable medications for the whole population (8).

A study evaluating the availability and accessibility of primary care medications in the Islamic Republic of Iran was conducted in 2004 and reported very good affordability of drugs and good availability of primary care drugs in public pharmacies (8). However, to the best of our knowledge, no study has been carried out so far to evaluate the availability and affordability of particular medicines for NCDs. Therefore, this study investigated the pricing, availability and affordability of selected medicines, used for NCDs in 2014 in order to provide comparable, evidence-based information for policymakers.

\section{Methods}

The methodology for assessing medicine price, availability, and affordability in this study was based on the one developed by the World Health Organization (WHO) and Health Action International (HAI). The survey approach involves the use of a systematic survey to collect data and information on the pricing, availability, and affordability of a core list of medicines in 2014, and provides guidance on reporting and on making policies aimed at resolving the problems. According to this methodology, each country is allowed to select a supplementary list of medicines on the basis of their importance in treating major national health problems (9). A validation study of the WHO/ HAI survey methodology done in Peru indicated that focusing on commonly used medicines from six regions could yield sufficient and valid results (10).

\section{Data collection}

The selected medicines were specified as a core list of medicines used in the treatment of NCDs with dosage forms and strengths to be surveyed for each medicine. The medicines included a global core list and a supplementary list. The supplementary list was discussed among experts trying to cover all four groups of NCD medicines including medicines of CVD, diabetes, COPD, and CNS. All the selected medicines were on the Iran National Essential Medicines List during the year 2014. The list was finalized after reaching a unanimous agreement.

The data was collected for 54 medicines from a total of 30 public retail pharmacies, 30 private community retail pharmacies, and 30 private pharmacies located inside public hospital (which are called other settings in this study) in Tehran and five provinces: Khorasan (Mashad), Yazd (Yazd), Sistan va Baluchistan (Zahedan), Gilan (Rasht), and Lorestan (Khoramabad). In the selection of the surveyed cities, the distance to the capital Tehran, population, and diversity in socioeconomical indexes were considered. The lists of health facilities and pharmacies were provided by IFDA regional branches. Data collection was conducted by 18 educated data collectors over two weeks. In addition to all three sectors, the procurement prices were obtained from the three major distributors. For each of the surveyed medicines, the data were collected for originator brand, most sold generic (MSG), and lowest priced generic (LPG) at each facility.

\section{Pricing}

The prices and availability of 17 iriginator brands products were recorded: Alprazolam, Amlodipine, Atorvastatin, Carbamazepine, Clopidogrel, Clozapine, Diclofenac, Digoxin, Enoxaparin syringe, Epoetin alpha injection, Hydrocortisone sod succ, Levothyroxine, Metformin, Methylphenidate HCL, Salbutamol inhaler, Sod. Valproate, and Sulphsalazine. However, no originator brand products for the rest of the medicines in the list could be found in the Islamic Republic of Iran. The WHO/HAI survey methodology presents prices in local currency and calculates median price ratios (MPR) in order to facilitate cross-country comparisons. The MPR is computed by dividing the local price by an international reference price in form of local currency.

Medicine Price Ratio (MPR) = median local unit price/ international reference unit price. An MPR of 1 means the local price is equivalent to the international reference price, whereas an MPR of 2 means the local price is twice the reference price.

In order to make comparisons feasible, the international reference prices used for this survey were extracted from the 2013 Management Sciences for Health (MSH) International Drug Price Indicator Guide. The MSH Guide collects information from recent price lists of not-profit and for-profit medicine suppliers for multisource medicines and thus reflects the prices governments could be expected to pay at the time of offering for medicines.

\section{Availability}

Availability of the medicines was evaluated in all the outlets surveyed and was expressed as the percentage of the outlets in each sector whereby the medicines were available.

\section{Affordability}

According to the methodology, routine regimens ("typical" treatments) of a number of NCDs were used to demonstrate the actual affordability for individual patients at a number of settings (9). Affordability was calculated as the number of days the lowest-paid unskilled 
government worker would have to work to pay for one month's treatment for the medicines for chronic conditions. In the Islamic Republic of Iran, whether in public or private sector, the lowest-paid unskilled government worker is on the minimum salary for all those earning a wage. At the time of the survey, the lowest-paid unskilled government worker earned 270000 Iranian Rials (IRR) (approximately US\$ 8 [2014]) per day. Having to spend more than one day's income per month on family medicine needs is considered to be unaffordable.

\section{Results}

\section{Availability}

The results from the availability of medicines survey, expressed as originator brand, most sold generic and lowest priced generic were depicted for all the three settings in Table 1. Across the 54 medicines, the mean availability of lowest priced generic in public sector facilities and private pharmacies, and other settings was $75.5 \%, 83.3 \%$, and $80.3 \%$, respectively. The medicines selected as most sold generic were available in nearly half of public facilities and private pharmacies (Figure 1).

The results from the availability survey indicated that the market was dominated by generics medicines. Of the 54 medicines surveyed, 18 were found in all 30 private pharmacies and only one in public health facilities on the day of data collection. Morphine injections were not found in any of the surveyed private pharmacies and retail pharmacies in public hospitals as they were not permitted. Moreover, of the 54 medicines surveyed, seven were found in all the 30 private retail pharmacies in public hospitals on the day of data collection (Table 2).

\section{Procurement prices}

The procurement prices to MPR are shown in Table 3. As it is displayed, in the Islamic Republic of Iran procurement prices were closest to the international reference price for most sold generic and lowest priced generic medicines. The median price for both generic versions was 1.19 times the international reference price; while the overall procurement price for the 11 originator brands

\begin{tabular}{|c|c|c|c|}
\hline Originator brand & $\begin{array}{l}\text { Most sold } \\
\text { generic }\end{array}$ & $\begin{array}{l}\text { Lowest } \\
\text { priced } \\
\text { generic }\end{array}$ & $\%$ \\
\hline \multicolumn{4}{|l|}{ In public health facilities } \\
\hline Mean availability (\%) & 25.5 & 46.4 & 75.5 \\
\hline $\mathrm{SD}^{*}$ availability (\%) & 27.4 & 21.0 & 20.9 \\
\hline \multicolumn{4}{|l|}{ In private pharmacies } \\
\hline Mean availability (\%) & 39.1 & 53.3 & 83.3 \\
\hline $\mathrm{SD}^{*}$ availability $(\%)$ & 33.3 & 25.9 & 25.2 \\
\hline \multicolumn{4}{|c|}{ In private pharmacies in public hospitals } \\
\hline Mean availability (\%) & 24.8 & 50.6 & 80.3 \\
\hline $\mathrm{SD}^{*}$ availability (\%) & 26.0 & 19.8 & 21.3 \\
\hline
\end{tabular}

found in all the three distributors was 4.02 times the international reference price. As mentioned earlier, public and private procurement systems are the same, and all three selected distributors provide medicines for pharmacies at both settings. Prices of originator brands and generic equivalents are significantly different from those of lowest priced generic and most sold generic.

\section{Public sector patient prices}

The results from the prices in public health facilities showed that in public facilities in the country, patient prices were closest to the international reference price for lowest priced generic medicines (interquartile range o.6-6.0) (Table 4). From among the 13 originator brands surveyed, nine medicines were found in the public sector facilities and these were four times the international reference price. There was negligible variation in the price of the same medicine in different pharmacies and regions, indicating that the adherence to the regulated prices by IFDA was strict.

\section{Private sector patient prices}

In private retail pharmacies, orifinator brand prices were about 3.5 times the international reference price and patient prices for most sold generic medicines were closest to the international reference price (interquartile range 0.15-5.58) (Table 5). As in the public sector, there was negligible variation in prices of the same medicine in private retail pharmacies in different pharmacies and regions.

\section{Other sector patient prices (private pharmacies located in public hospitals)}

In the private pharmacies located in public hospitals, originator brands were 3.88 times higher than the international reference price, and lowest priced generics, like most sold generics, were about 1.19 times the international reference prices (Table 6). Similar to the other two settings, there was negligible variation in prices of the same medicine in different pharmacies and regions. Prices in the private pharmacies located in public hospitals were the same as those in private retail pharmacies, reflecting reflect the regulated retail price.

\section{Inter-sectoral comparisons}

As shown in Table 7, lowest priced generics had the highest availability at all the three settings and originator brands had the highest availability in private pharmacies. There were not any significant differences the between the settings in the availability of medicine.

\section{Affordability}

The affordability of treating seven of the NCDs causing high rates of morbidity and mortality was assessed by comparing the total cost of medicines prescribed at a standard dose. This index was applied to the daily wage of the lowest-paid unskilled government worker (US \$8 per day) in Iran at the time of the survey. The result showed that less than one day's wage was needed to purchase all treatments (Table 8). If a typical Iranian worker needed 


\begin{tabular}{|c|c|}
\hline Availability & Medicine \\
\hline \multicolumn{2}{|c|}{ In public health facilities } \\
\hline Not found & - \\
\hline$<50 \%$ & Carvedilol, Methylphenidate, Levodopa/carbidopa, Tamoxifen, Digoxin, Clozapine, Enoxaparin injection, Fluphenazine injection \\
\hline $50-60 \%$ & Lithium, morphine, Epoetin alpha, Gliclazide, Simvastatin, Sulphasalazine \\
\hline $61-80 \%$ & $\begin{array}{l}\text { Losartan, Folic acid, Chlorpromazine injection, Beclometasone inhaler, Diclofenac, Clopidogrel, Furosemide, Spironolactone, } \\
\text { Dimenhydrinate }\end{array}$ \\
\hline $81-99 \%$ & $\begin{array}{l}\text { Amlodipine, Atenolol, Glibenclamide, Paracetamol, Valproate, Timolol eye drops, Alprazolam, Amitriptyline, Cetirizine, Epinephrine } \\
\text { injection, Hydrocortisone sod succ, Ibuprofen, Isosorbide dinitrate, Levothyroxine, Omeprazole, Atorvastatin, Fluoxetine, } \\
\text { Hydrochlorothiazide, Metformin, Phenobarbital, Phenytoin, Trihexylphenidyl, Carbamazepine, Diazepam, Enalapril, Isophane } \\
\text { human insulin, Prednisolone, Salbutamol syrup, Neutral sol human insulin, Salbutamol inhaler }\end{array}$ \\
\hline $100 \%$ & Dexamethasone injection \\
\hline \multicolumn{2}{|c|}{ In private retail pharmacies } \\
\hline Not found & Morphine injection \\
\hline$<50 \%$ & Digoxin, Epinephrine injection, Fluphenazine injection \\
\hline $50-60 \%$ & Epoetin alpha, Carvedilol, Chlorpromazie \\
\hline $61-80 \%$ & Sulphasalazine, Tamoxifen, Clozapine, Hydrocortisone \\
\hline $81-99 \%$ & $\begin{array}{l}\text { Valproate, Spironolactone, Beclometasone inhaler, Diazepam, Gliclazide, Isophane human insulin, Lithium carbonate, Clopidogrel, } \\
\text { Dimenhydrinate, Isosorbide dinitrate, Levothyroxine, Metformin, Neutral sol human insulin, Phenobarbital, Phenytoin, Simvastatin, } \\
\text { Trihexylphenidyl, Alprazolam, Amitriptyline, Atorvastatin, Furosemide, Salbutamol inhaler, Salbutamol syrup }\end{array}$ \\
\hline $100 \%$ & $\begin{array}{l}\text { Amlodipine, Atenolol, Carbamazepine, Cetirizine, Dexamethasone injection, Diclofenac, Enalapril, Fluoxetine, Folic acid, } \\
\text { Glibenclamide, Hydrochlorothiazide, Ibuprofen, Losartan, Omeprazole, Paracetamol, Prednisolone, Timolol maleate eye drops, Acetyl } \\
\text { salicyclic acid }\end{array}$ \\
\hline \multicolumn{2}{|c|}{ In private retail pharmacies located in public hospitals } \\
\hline \multicolumn{2}{|l|}{ Not found } \\
\hline$<50 \%$ & Carvedilol, Sulphsalazine, Fluphenazine injection, Tamoxifen citrate, Enoxaparin syringe, Methylphenidate HCL \\
\hline $50-60 \%$ & Levodopa + carbidopa, Epoetin alpha injection, Morphine injection, Digoxin \\
\hline $61-80 \%$ & $\begin{array}{l}\text { Dimenhydrinate, Phenobarbital, Lithium carbonate, Sod. Valproate, Phenytoin, Clozapine, Simvastatin, Chlorpromazine injection, } \\
\text { Epinephrine injection, Gliclazide, Spironolactone, Acetyl salicyclic acid }\end{array}$ \\
\hline $81-99 \%$ & $\begin{array}{l}\text { Amlodipine, Atenolol, Dexamethasone injection, Fluoxetine, Glibenclamide, Isophane human insulin, Isosorbide dinitrate, } \\
\text { Levothyroxine, Amitriptyline, Beclometasone inhaler, Carbamazepine, Cetirizine, Enalapril, Folic acid, Furosemide, Losartan, } \\
\text { Metformin, Prednisolone, Salbutamol inhaler, Diclofenac, Neutral sol human insulin, Salbutamol syrup, Timolol maleate eye drops, } \\
\text { Clopidogrel, Diazepam, Hydrocortisone sod succ }\end{array}$ \\
\hline $100 \%$ & Alprazolam, Atorvastatin, Hydrochlorothiazide, Ibuprofen, Omeprazole, Paracetamol, Trihexylphenidyl \\
\hline
\end{tabular}

\begin{tabular}{lccc}
\hline $\begin{array}{l}\text { Table 3: Procurement prices compared to international } \\
\text { reference prices (MPR) }\end{array}$ & $\begin{array}{c}\text { Most sold } \\
\text { generic }\end{array}$ & $\begin{array}{c}\text { Lowest } \\
\text { priced } \\
\text { generic }\end{array}$ & $\%$ \\
\hline $\begin{array}{l}\text { Number of } \\
\text { medications included }\end{array}$ & 11 & 51 & 54 \\
Median MPR & 4.02 & 1.19 & 1.19 \\
25\% percentile MPR & 2.95 & 0.65 & 0.65 \\
$75 \%$ percentile MPR & 16.71 & 2.21 & 2.10 \\
Minimum MPR & 0.72 & 0.15 & 0.15 \\
Maximum MPR & 23.53 & 5.58 & 5.58 \\
\hline
\end{tabular}

treatment for hypertension, arthritis, and a peptic ulcer, he had to pay less than half a day's wage every month to purchase the required medicines. The exception was the $\mathrm{OB}$ of atorvastatin that required about four days' wages to purchase one month's treatment.

\begin{tabular}{lccc}
\hline $\begin{array}{l}\text { Table 4: Public sector prices compared to international } \\
\text { reference prices (MPR) }\end{array}$ & $\begin{array}{c}\text { Originator } \\
\text { brand }\end{array}$ & $\begin{array}{c}\text { Most sold } \\
\text { generic }\end{array}$ & $\begin{array}{c}\text { Lowest } \\
\text { priced } \\
\text { generic }\end{array}$ \\
\hline $\begin{array}{l}\text { Number of } \\
\text { medications included }\end{array}$ & 9 & 52 & 54 \\
Median MPR & 4.02 & 1.11 & 1.05 \\
25\% percentile MPR & 2.38 & 0.64 & 0.63 \\
$75 \%$ percentile MPR & 22.36 & 2.19 & 1.99 \\
Minimum MPR & 1.12 & 0.15 & 0.15 \\
Maximum MPR & 23.53 & 5.58 & 5.58 \\
\hline
\end{tabular}

\section{Discussion}

The present study is to the best of our knowledge the only one that evaluated the procurement and patient prices and the availability of medicines for NCDs in three different dispensing areas in the Islamic Republic 
Table 5: Patient prices in private pharmacies compared to international reference prices (MPR)

\begin{tabular}{lccc} 
& $\begin{array}{c}\text { Originator } \\
\text { brand }\end{array}$ & $\begin{array}{c}\text { Most sold } \\
\text { generic }\end{array}$ & $\begin{array}{c}\text { Lowest } \\
\text { priced } \\
\text { generic }\end{array}$ \\
\hline $\begin{array}{l}\text { Number of } \\
\text { medications included }\end{array}$ & 14 & 50 & 53 \\
Median MPR & 3.50 & 1.18 & 1.19 \\
25\% percentile MPR & 1.58 & 0.66 & 0.66 \\
$75 \%$ percentile MPR & 10.45 & 2.23 & 2.02 \\
Minimum MPR & 0.66 & 0.15 & 0.15 \\
Maximum MPR & 23.53 & 5.58 & 5.58 \\
\hline
\end{tabular}

Table 6: Patient prices in private retail pharmacies in public hospitals (MPR)

\begin{tabular}{lccc} 
& $\begin{array}{c}\text { Originator } \\
\text { brand }\end{array}$ & $\begin{array}{c}\text { Most sold } \\
\text { generic }\end{array}$ & $\begin{array}{c}\text { Lowest } \\
\text { priced } \\
\text { generic }\end{array}$ \\
\hline $\begin{array}{l}\text { Number of } \\
\text { medications included }\end{array}$ & 10 & 53 & 54 \\
Median MPR & 3.88 & 1.19 & 1.19 \\
$25 \%$ percentile MPR & 2.60 & 0.65 & 0.65 \\
$75 \%$ percentile MPR & 10.45 & 2.17 & 2.01 \\
Minimum MPR & 1.12 & 0.15 & 0.15 \\
Maximum MPR & 23.53 & 5.58 & 5.58 \\
\hline
\end{tabular}

\begin{tabular}{lccc}
\hline \multicolumn{4}{l}{ Table 7: Availability of the medicines in each sector } \\
& OB & MSG & LPG \\
\hline Procurement & 11 & 51 & 54 \\
Public sector & 9 & 52 & 54 \\
Private sector & 14 & 50 & 53 \\
$\begin{array}{l}\text { Private pharmacies } \\
\text { in public hospitals }\end{array}$ & 10 & 53 & 54 \\
\hline OB=Originator Brand, $M S G=$ Most Sold Generic, $L P G=$ Lowest Priced Generic
\end{tabular}

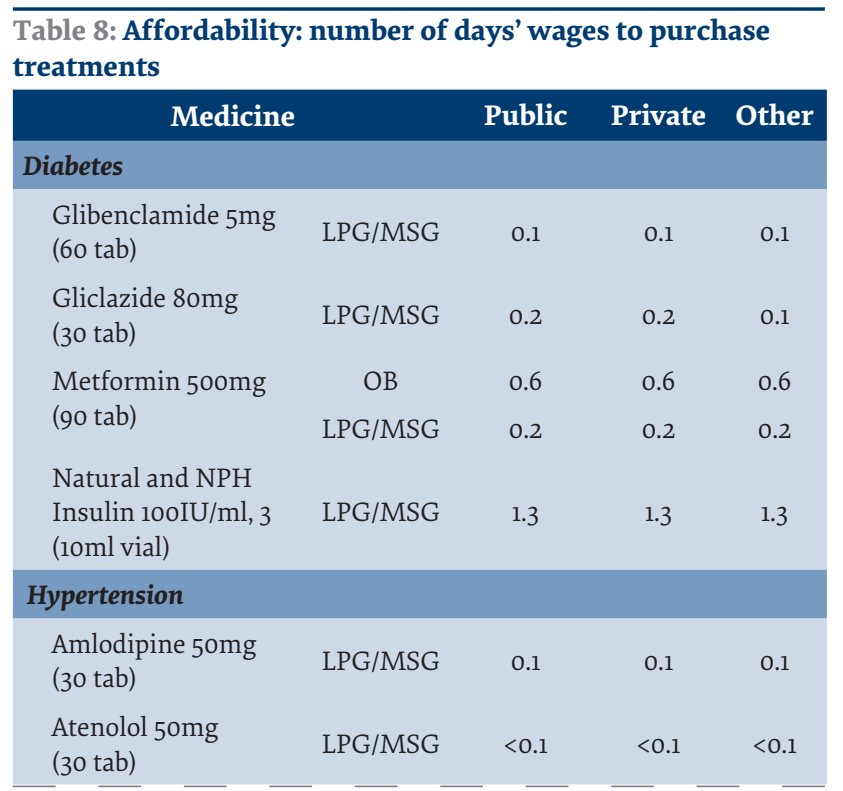

\begin{tabular}{|c|c|c|c|c|}
\hline \multicolumn{2}{|l|}{ Medicine } & \multirow{2}{*}{$\begin{array}{c}\text { Public } \\
\quad<0.1\end{array}$} & \multirow{2}{*}{$\begin{array}{c}\text { Private } \\
\quad<0.1\end{array}$} & \multirow{2}{*}{$\begin{array}{l}\text { Other } \\
<0.1\end{array}$} \\
\hline $\begin{array}{l}\text { Hydrochlorothiazide } \\
\text { (30 tab) }\end{array}$ & LPG/MSG & & & \\
\hline \multicolumn{5}{|l|}{ Hyperlipidaemia } \\
\hline \multirow{2}{*}{$\begin{array}{l}\text { Atorvastatin 2omg } \\
\text { (30 tab) }\end{array}$} & $\mathrm{OB}$ & 4.1 & 4.1 & 4.1 \\
\hline & LPG/MSG & 0.2 & 0.2 & 0.2 \\
\hline \multirow{2}{*}{$\begin{array}{l}\text { Simvastatin 20mg } \\
\text { (30 tab) }\end{array}$} & LPG/MSG & 0.2 & 0.2 & 0.2 \\
\hline & 26.0 & 19.8 & 21.3 & \\
\hline \multicolumn{5}{|l|}{ Arthritis } \\
\hline $\begin{array}{l}\text { Diclofenac 50mg } \\
\text { (60 tab) }\end{array}$ & LPG/MSG & 0.1 & 0.1 & 0.1 \\
\hline \multicolumn{5}{|l|}{ Peptic ulcer } \\
\hline $\begin{array}{l}\text { Omeprazole 2omg } \\
\text { (30 tab) }\end{array}$ & LPG/MSG & 0.2 & 0.2 & 0.2 \\
\hline \multicolumn{5}{|l|}{ Asthma } \\
\hline $\begin{array}{l}\text { Beclometasone } \\
\text { inhaler }\end{array}$ & LPG/MSG & 0.3 & 0.3 & 0.3 \\
\hline Salbutamol inhaler & LPG/MSG & 0.3 & 0.3 & 0.3 \\
\hline \multicolumn{5}{|l|}{ Epilepsy } \\
\hline \multirow{2}{*}{$\begin{array}{l}\text { Carbamazepine } \\
\text { 20omg (150 tab) }\end{array}$} & OB & - & 2.5 & 2.5 \\
\hline & LPG/MSG & 0.5 & 0.5 & 0.5 \\
\hline
\end{tabular}

of Iran. The study also assessed the affordability of the treatments according to the WHO/HAI methodology. According to the methodology, the availability less than $30 \%$ describes very low, and those of $30-49 \%, 50-80 \%$, and more than $80 \%$ describe low, fairly high, and high availability, respectively (9). In order to draw comparisons among countries, the method employs the following cut-off points for MPRs to represent acceptable local price ratios (8):

- Public sector - procurement price: $M P R \leq 1$

- Public sector - patient price: $M P R \leq 1.5$

- Private retail pharmacy - patient price: $M P R \leq 2.5$

Hence, in a low or middle-income country like Iran, an MPR of less than or equal to 1 for public sector procurement prices and public sector patient prices indicates acceptable (not excessive) prices (9).

The main finding of the study was that the availability and affordability of the selected medicines for NCDs were relatively good for lowest priced generics and most sold generics but not for originator brands. The availability of the generic medicines was relatively good at both public and private settings in the country. The mean availability of lowest priced generic form of the surveyed medicines was fairly high in public pharmacies and high in private pharmacies and other settings. The mean availability of most sold generic ones was low in public pharmacies and fairly high in private pharmacies and other settings. Furthermore, the availability of originator brands medicines seemed to be very low or low in the country, which could be associated with their relatively 
Figure 1: Median MPR for medicines with minimum no. of prices

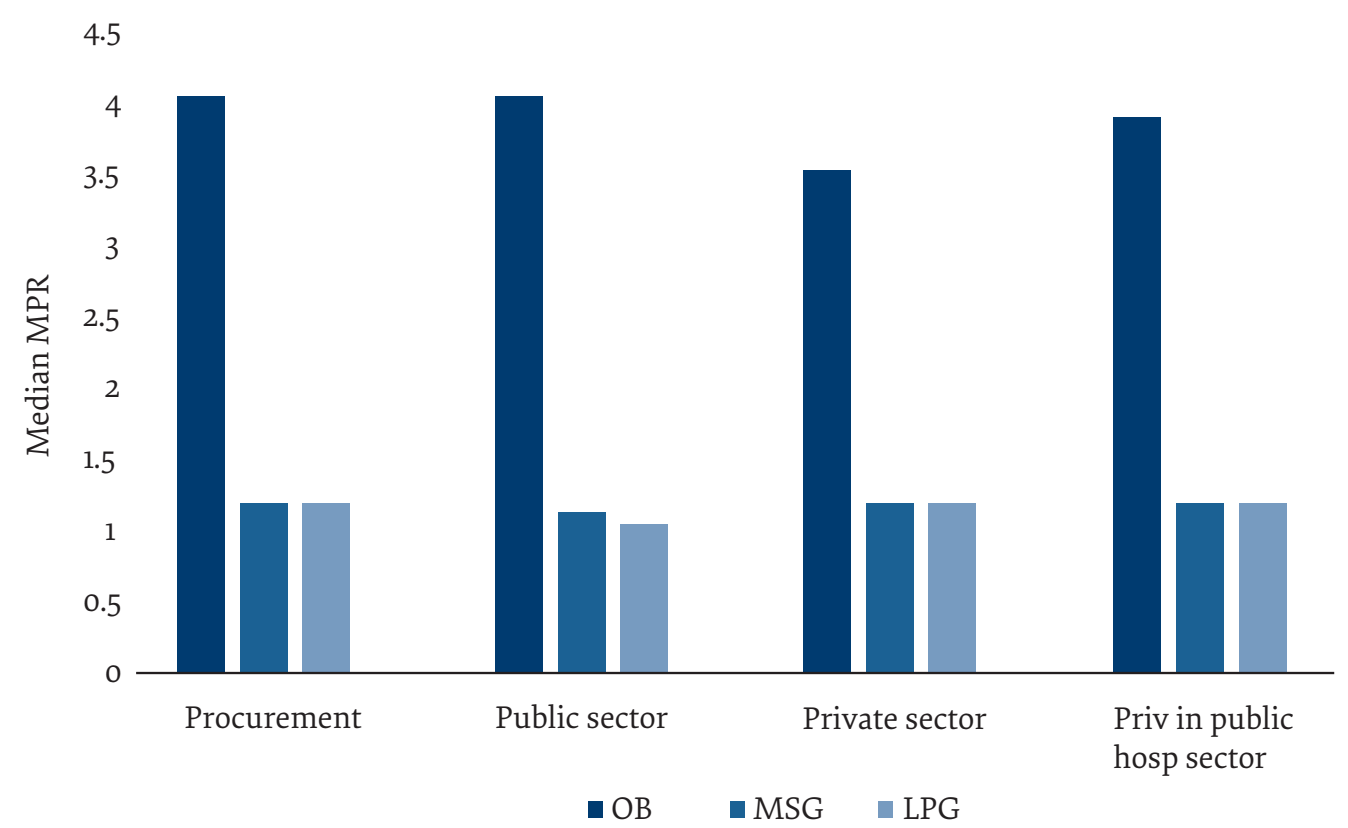

$\mathrm{OB}=$ Originator Brand, MSG= Most Sold Generic, LPG= Lowest Priced Generic, Procurement= Procurement prices, Public sector= Public pharmacies, Private sector= Private pharmacies, Priv in public hosp sector $=$ Private pharmacy in public hospital sector

higher prices compared to generics. However, originator brand medicines were more available in the private sector, which could be due to competitive pharmaceutical distributors.

The study also revealed that lowest priced generics were the predominant type of medicine available at all the three settings, which is consistent with other studies using the same methodology (11). The Iranian "Generic Scheme" that started in 1980 was successful in improving accessibility to medications, especially during the 1980s (12). The national generic medicines policy promotes and enforces the prescribing and dispensing of generic medicines. This finding can be consistent with previous studies (13) indicating that the Generic Scheme, started in the 1980s, helped improve accessibility to medicines through decreasing the price of pharmaceuticals and improving national distribution. Nevertheless, some other studies argue that this has also lead to overconsumption, over-use of health care services in the past years, and misuse of some medications (14) In the Islamic Republic of Iran, originator brand medicines are more expensive and less available than most sold generics and lowest priced generics; thus, most people have to purchase generic medicines. This finding is also consistent with the previous studies $(15,16)$. In the majority of countries, the price of originator brands is higher than those of the two other forms $(17,18)$.

The treatments for seven important NCDs cost less than one day's wage for the lowest-paid government worker except for insulin that was costly. Most sold generics or lowest priced generics were reasonably affordable for most conditions while the monthly treatments of two originator brands cost over a day's wage (carbamazepine and atorvastation). It should be noted that the prices did not vary greatly across the three settings.

It is important to note the fact that even in cases where individual treatment seems affordable, some persons or families in need of multiple medications might find it unaffordable (19). As outlined by another study (20), the WHO/HAI methodology has some limitations despite its strengths. Firstly, availability refers only to the day of the data collection, which might not represent availability over time. Secondly, alternative dosage forms and strengths are not taken into account. Finally, the affordability measure does not include all potential healthcare cost such as diagnostic tests.

This study can have crucial implications for national policy-makers. Some countries such as Lebanon and India (21) used the results of medicines price and availability in order to inform the decision and health policy-makers and compose guidelines for improving access to essential medicines. Moreover, using WHO/HAI methodology makes it possible to compare the results with those in other countries in the region or at the same economic level.

\section{Conclusion}

In summary, the study set out to explore the availability, pricing, and affordability of essential medicines for NCDs. The data for 54 medicines was collected from public and private sector retail pharmacies and private pharmacies in public hospitals in six Iranian cities on the basis of the standardized methodology developed by the 
WHO/HAI. Affordability and mean availability of generic medicines were relatively acceptable across the three settings while $\mathrm{OB}$ medicines had lower availability and affordability. The present survey provided a clear picture of the availability, pricing and affordability of essential medicines for NCDs in 2014 in the country. The findings contain important information that policy-makers could use to improve health care policies.

\section{Acknowledgements}

The authors would like to thank Health Action International for their technical support and for maintaining the database of the survey results and making it publicly and freely accessible on their website.

Funding: None.

Competing interests: None declared.

\section{Disponibilité, prix et accessibilité économique d'une sélection de médicaments pour la prise en charge des maladies non transmissibles}

\section{Résumé}

Contexte : La charge nationale et mondiale des maladies non transmissibles continue de croître, ce qui donne davantage d'importance à la question de l'accès aux médicaments

Objectifs : La présente étude visait à évaluer la disponibilité et l'accessibilité économique d'une sélection de médicaments pour la prise en charge des maladies non transmissibles et la fixation de leur prix en République islamique d'Iran à l'aide de la méthodologie mise au point par l'Organisation mondiale de la Santé/Health Action International.

Méthode : Les données sur les prix et la disponibilité de 54 médicaments sélectionnés ont été recueillies auprès de pharmacies de détail publiques et privées ainsi que de pharmacies privées situées dans des hôpitaux publics de six villes de la République islamique d'Iran sur la base de la méthodologie normalisée élaborée par l'Organisation mondiale de la Santé (OMS) et Health Action International (HAI). Les résultats ont été mesurés en termes de pourcentage de la disponibilité des médicaments, de ratios des prix des médicaments par rapport aux prix de référence internationaux et d'accessibilité économique. Cette dernière a été définie comme le nombre de jours de salaire nécessaires au fonctionnaire non qualifié le moins bien rémunéré pour se permettre un mois de traitement chronique.

Résultats : Le prix d'achat du médicament générique le moins cher et du médicament générique le plus vendu dans l'étude était 1,19 fois le prix de référence international. Le prix payé par les patients ne variait pas significativement entre les différents établissements de vente au détail en pharmacie par rapport aux prix de référence internationaux. De plus, la disponibilité moyenne globale des médicaments génériques les moins chers inclus dans cette étude dans les établissements publics, privés et autres était de 75,5\%,83,3\% et 80,3\%, respectivement. Tous les coûts de prise en charge des maladies non transmissibles les plus lourdes étaient inférieurs au salaire journalier du fonctionnaire le moins bien payé.

Conclusions : Cette étude a montré que les prix d'achat des médicaments étudiés étaient raisonnables par rapport au prix de référence internationaux. De plus, la disponibilité des formes génériques des médicaments étudiés était bonne, mais celles des médicaments de marque d'origine étaient très faibles dans les trois types d'établissements.

$$
\begin{aligned}
& \text { مدى توافر أدوية محددة لعلاج الأمر اض غير السارية وأسعارها والقدرة على تحمل تكاليفها } \\
& \text { إلهام حيدري، مهدي ورمقاني، أكبر عبداللهي أصل } \\
& \text { الخلاصة } \\
& \text { الخلفية: لا يز ال العبء العالمي والوطني للأمر اض غير السارية في ازدياد، ما يزيد من أهمية الحصول على الأدوية. }
\end{aligned}
$$

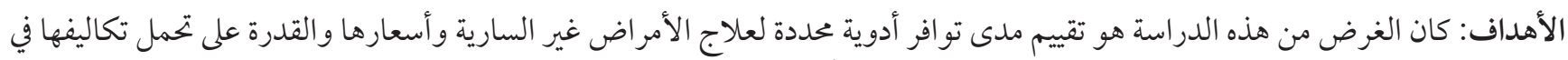

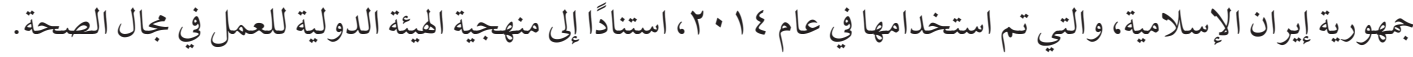

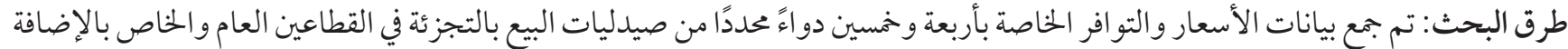

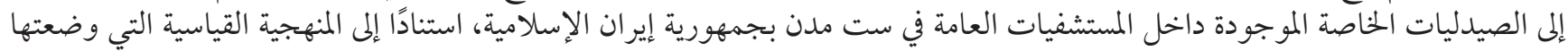

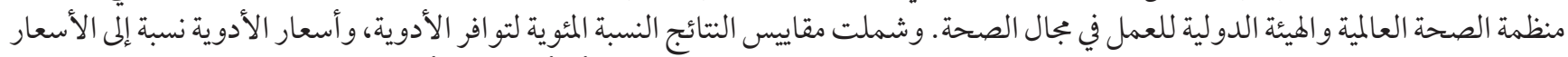

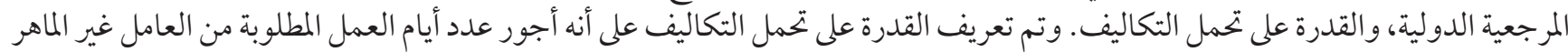

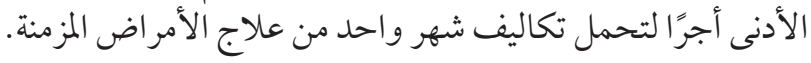




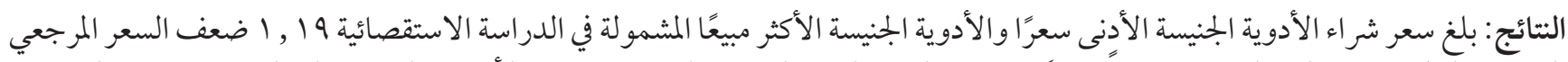

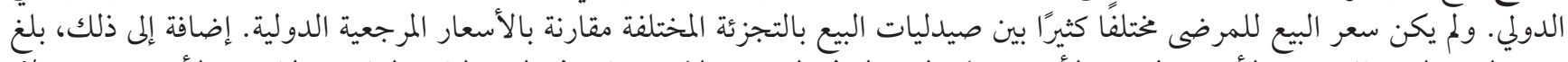

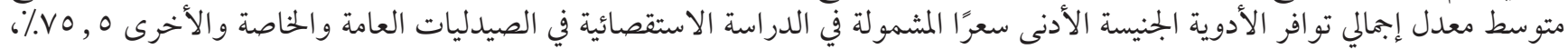

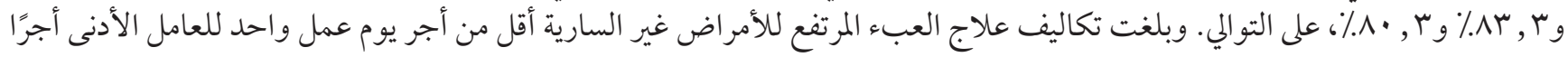

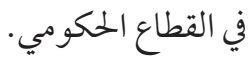

الاستنتاجات: أشارت هذه الدراسة إلى أن أسعار شراء الأدوية المشمولة في الدراسة الاستقصائية تعد معقولة مقارنة بالسعر المرجعي الدولي.

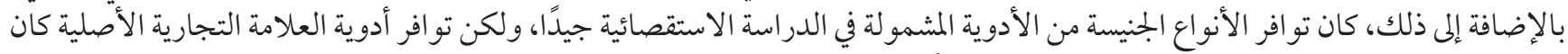

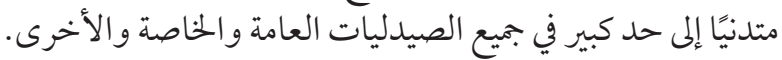

\section{References}

1. Abegunde DO, Mathers CD, Adam T, Ortegon M, Strong K. The burden and costs of chronic diseases in low-income and middle-income countries. Lancet. 2007;370(9603):1929-38. http://dx.doi.org/10.1016/So140-6736(07)61696-1

2. World Health Organization. WHO NCD surveillance strategy. Geneva: World Health Organization; 2010 (https://www.who.int/ ncd_surveillance/strategy/en).

3. Daar AS, Singer PA, Leah Persad D, Pramming SK, Matthews DR, Beaglehole R, et al. Grand challenges in chronic non-communicable diseases. Nature. 2007;450(7169):494-6. http://dx.doi.org/10.1038/450494a

4. Esteghamati A, Meysamie A, Khalilzadeh O, Rashidi A, Haghazali M, Asgari F, et al. Third national Surveillance of Risk Factors of Non-Communicable Diseases (SuRFNCD-2007) in Iran: methods and results on prevalence of diabetes, hypertension, obesity, central obesity, and dyslipidemia. BMC Public Health. 2009;9(1):167. http://dx.doi.org/10.1186/1471-2458-9-167

5. Askarian M, Mansour Ghanaie R, Karimi A, Habibzadeh F. Infectious diseases in Iran: a bird's eye view. Clin Microbiol Infect. 2012;18(11):1081-8. http://dx.doi.org/10.1111/1469-0691.12021

6. Varmaghani M, Hashemi-Meshkini A, Abdollahiasl A, Heidari E, Zekri HS, Yaghoubifard S, et al. An overview to pharmaceutical financing in Iran. J Pharmacoeconomics \& Pharm Manage. 2016;2(1-2):45-9.

7. Zargaran M, Nikfar S, Cheraghali AM. Evaluation of prescriptions of medicines not included in Iran medicine list: A cross-sectional study. J Res Pharm Pract. 2016;5(4):234-7. http://dx.doi.org/10.4103/2279-042X.192456

8. Cheraghali AM, Nikfar S, Behmanesh Y, Rahimi V, Habibipour F, Tirdad R, et al. (2004). Evaluation of availability, accessibility and prescribing pattern of medicines in the Islamic Republic of Iran. East Mediterr Health J. 2004 May;10(3):406-15.

9. Price, availability and affordability: an international comparison of chronic disease medicines. Cairo: World Health Organization Regional Office for the Eastern Mediterranean; 2006 (http://www.who.int/iris/handle/10665/116493).

10. Madden JM, Meza E, Ewen M, Laing RO, Stephens P, Ross-Degnan D. Measuring medicine prices in Peru: validation of key aspects of WHO/HAI survey methodology. Rev Panam Salud Publica. 2010;27(4):291-9. http://dx.doi.org/10.1590/S102049892010000400008

11. Davari M, Haycox A, Walley T. Health care financing in Iran; is privatization a good solution? Iran J Public Health. 2012;41(7):14.

12. Nikfar S, Kebriaeezadeh A, Majdzadeh R, Abdollahi M. Monitoring of National Drug Policy (NDP) and its standardized indicators; conformity to decisions of the national drug selecting committee in Iran. BMC Int Health Hum Rights. 2005;5(1):5. PMID: 15885139

13. Davari M, Walley T, Haycox A. Pharmaceutical policy and market in Iran: past experiences and future challenges. J Pharm Health Serv Res. 2011;2(1):47-52. http://dx.doi.org/10.1111/j.1759-8893.2011.00042.x

14. Nguyen AT, Knight R, Mant A, Cao QM, Auton M. Medicine prices, availability, and affordability in Vietnam. Southern Med Review (2009) 2; 2:2-9

15. Anson A, Ramay B, de Esparza AR, Bero L. Availability, prices and affordability of the World Health Organization's essential medicines for children in Guatemala. Global Health. 2012;8(1):22. http://dx.doi.org/10.1186/1744-8603-8-22

16. Chahal HS, Fort NS, Bero L. Availability, prices and affordability of essential medicines in Haiti. J Glob Health. 2013;3(2):020405 http://dx.doi.org/10.7189/jogh.03.020405

17. Babar Z-U-D, Lessing C, Mace C, Bissell K. The availability, pricing and affordability of three essential asthma medicines in 52 low-and middle-income countries. Pharmacoeconomics. 2013;31(11):1063-82. http://dx.doi.org/10.1007/s40273-013-0095-9

18. Abdollahiasl A, Kebriaeezadeh A, Dinarvand R, Abdollahi M, Cheraghali A, Jaberidoost M, et al. A system dynamics model for national drug policy. Daru. 2014;22(1):34. http://dx.doi.org/10.1186/2008-2231-22-34

19. Jiang M, Yang S, Yan K, Liu J, Zhao J, Fang Y. Measuring access to medicines: a survey of prices, availability and affordability in Shaanxi Province of China. PLoS One. 2013;8(8):e70836.

20. Cameron A, Ewen M, Ross-Degnan D, Ball D, Laing R. Medicine prices, availability, and affordability in 36 developing and middle-income countries: a secondary analysis. Lancet. 2009;373(9659):240-9. http://dx.doi.org/10.1016/So140-6736(08)61762-6

21. Kotwani A. Where are we now: assessing the price, availability and affordability of essential medicines in Delhi as India plans free medicine for all. BMC Health Serv Res. 2013;13(1):285. http://dx.doi.org/10.1186/1472-6963-13-285 